\title{
Entrepreneurial migrants from/in emerging economies: breaking taboos and stereotypes
}

\author{
Maribel Guerrero ${ }^{1,2} \cdot$ Roseline Wanjiru ${ }^{2}$
}

Accepted: 27 April 2021 / Published online: 21 May 2021

(C) The Author(s), under exclusive licence to Springer Science+Business Media, LLC, part of Springer Nature 2021

\begin{abstract}
Entrepreneurial migration from/in emerging economies, as grand societal and humanitarian challenges that we currently face, underscores the need for scholarly research. In our role as social science researchers, this special issue aimed to stimulate scholars from different social science fields to rethink more broadly about the opportunities for making an impact with our research focus on entrepreneurial migration from/in emerging economies. This article provides an overview of the theoretical, empirical, managerial, and policy implications of entrepreneurial migrants from/in emerging economies research. It puts forward key concepts and measures, explores the relations within the current broader literature on migration and entrepreneurship, and identifies several gaps that represent future research questions. We also introduce eight papers in a special section of this issue, which offer answers to critical gaps and questioning some taboos/stereotypes related entrepreneurial migrants. We conclude by outlining an agenda for engaging the academic community to extend research on entrepreneurial migrants from/in emerging economies. It is the perfect time to "make a difference" through our research, teaching, and interaction with multiple socioeconomic agents to constitute impacts that "endorse a real transformation" for supporting the migrants' community.
\end{abstract}

Keywords Migrants $\cdot$ Emigrants $\cdot$ Immigrants $\cdot$ Refugees $\cdot$ Returned $\cdot$ Entrepreneurship $\cdot$ Institutions $\cdot$ Emerging Economies

Maribel Guerrero

maribel.guerrero@northumbria.ac.uk

1 Faculty of Economics and Business, Universidad del Desarrollo, Santiago, Chile

2 Northumbria Centre for Innovation, Regional Transformation, and Entrepreneurship (iNCITE), Newcastle Business School, Northumbria University, Newcastle upon Tyne, UK 


\section{Introduction}

The 79th Annual Meeting of the Academy of Management (AOM) theme was "Understanding the Inclusive Organization". At that moment, the United Nations (2017) had reported that more than 257 million people had migrated outside of their home countries for more than twelve months. According to International Organization for Migration, migrants are understood as persons who move away from their place of usual residence, whether within a country or across an international border, temporarily or permanently, and for a variety of reasons (IOM, 2019, p. 132). Remarkably, while the global migration phenomenon has represented a "grand societal and humanitarian challenge", the accumulated literature (Bates, 2011; AliagaIsla \& Rialp, 2013; Naudé et al., 2015; Dabić et al., 2020; Desai et al., 2021) and empirical evidence (United Nations, 2017; BBVA, 2019; IOM, 2020) continue still highlighted relevant gaps in the academic debate.

Three important points have motivated our focus on entrepreneurial migrants from/in emerging economies. First, the reported numbers in 2017 have increased three times more than the numbers reported in 1990 (United Nations, 2017; UNHCR, 2018). However, little is still known about how human migration within and among emerging economies has impacted the home/host countries' entrepreneurial dynamic, labor market configuration, organizational strategic management practices, and the design/effectiveness of inclusive migratory policy frameworks. Second, scholars have contributed with insights across different disciplines but mainly focused on individuals' mobility from emerging economies into developed countries (Levie, 2007; Aliaga-Isla \& Rialp, 2013; Dheer, 2018; Mawson \& Kasem, 2019). Indeed, the most updated UNHCR statistics ${ }^{1}$ show that developing countries have hosted at least $86 \%$ of the world's refugees and displacements abroad. Yet, anecdotal evidence has exposed the migratory flow among emerging economies. Third, scholars have recognized the persistence of "taboos", "stereotypes", and "myths" about migrant entrepreneurs (De Haas, 2005; Dabić et al., 2020; Desai et al., 2021). Theoretical and empirical studies are still needed to validate existing patterns or break these stereotypes, taboos, and myths. Four, a few empirical evidence has suggested a positive impact on value creation, job creation, and innovation generated by the migrants from emerging economies into transitional economies (Ratha et al., 2011; Huang, 2012; Skeldon, 2012; Harima, 2014; Liu et al., 2019; RodríguezGutiérrez et al., 2019). Consequently, the (positive/negative) impacts of migrant entrepreneurs within and among emerging economies are still unexplored.

Inspired by these trends and the AOM Entrepreneurship Division sponsorship, we organized the PDW entitled "Entrepreneurial Migrants from and in Emerging Economies". The active participation from multiple AOM divisions members generated a provoking academic debate about the broad range of perspectives to understand better the determinants and the consequences of migration from/in emerging economies (e.g., Africa, Asia, Latin-America, and Eastern Europe) upon

\footnotetext{
${ }^{1}$ For further details, review the UNHCR statistics [https://www.unhcr.org/refugee-statistics/]
} 
entrepreneurship. As a result of this academic debate, we identified multiple migratory pathways, multiple research experiences, and conceptual/methodological challenges. Then, we defined a collaborative research agenda about migrant entrepreneurship from and in emerging economies summarized in the following four aims of this Special Issue (SI):

(a) to legitimize this under-represented collective's participation and contribution (migrants from/in emerging economies) in the host entrepreneurship community.

(b) to offer a more inclusive research space to understand better determinants and consequences of migration from/in emerging economies.

(c) to generate scholarly implications to agents involved in home and host entrepreneurship ecosystems (policymakers, universities, labor market, technology transfer infrastructures, ONGs, and among others).

(d) to validate existing trends or break taboos and stereotypes about migrant entrepreneurs from/in emerging economies (e.g., non-skilled, non-innovative, nonexporting, non-productive, and among others).

The remainder of this paper is organized as follows. Background clarifies the definitions and the measurements of entrepreneurial migrants from/in emerging economies. Entrepreneurial migrants taboos and stereotypes introduces a review of the taboos and stereotypes of entrepreneurial migrants from/in emerging economies. Special issue's contributions focused on the contributions of this special issue and lessons that we learned across emerging economies. In Proposed research agenda, we outline an agenda for additional research on this topic. In the final section, we conclude by outlining policy implications.

\section{Background}

\section{Defining and measuring migration}

Although the accumulated literature has recognized the unified definitions from the official international organisms (Naudé et al., 2015; Dabić et al., 2020; Desai et al., 2021), the academic studies about "migration" have also used diverse terms or concepts (e.g., internal or external migration, emigration, immigration, refugees migration or seasonal migration). Given the diversity in terminologies, Table 1 shows the most representative types and definitions of human migration applied by practitioners, policymakers, and academics. We observe a consensus in defining migration as the movement of people from their usual residence place across international borders (external migration) or within the country (internal migration) (IOM, 2019). However, the definition varies according to the duration (short term or long term), the crossing of borders (internal or external), the perspective of the country of origin (emigration) or destination (immigration), the reason or purpose of moving (by a conflict) as well as the decision of returning to the country of origin (voluntary or forced). 


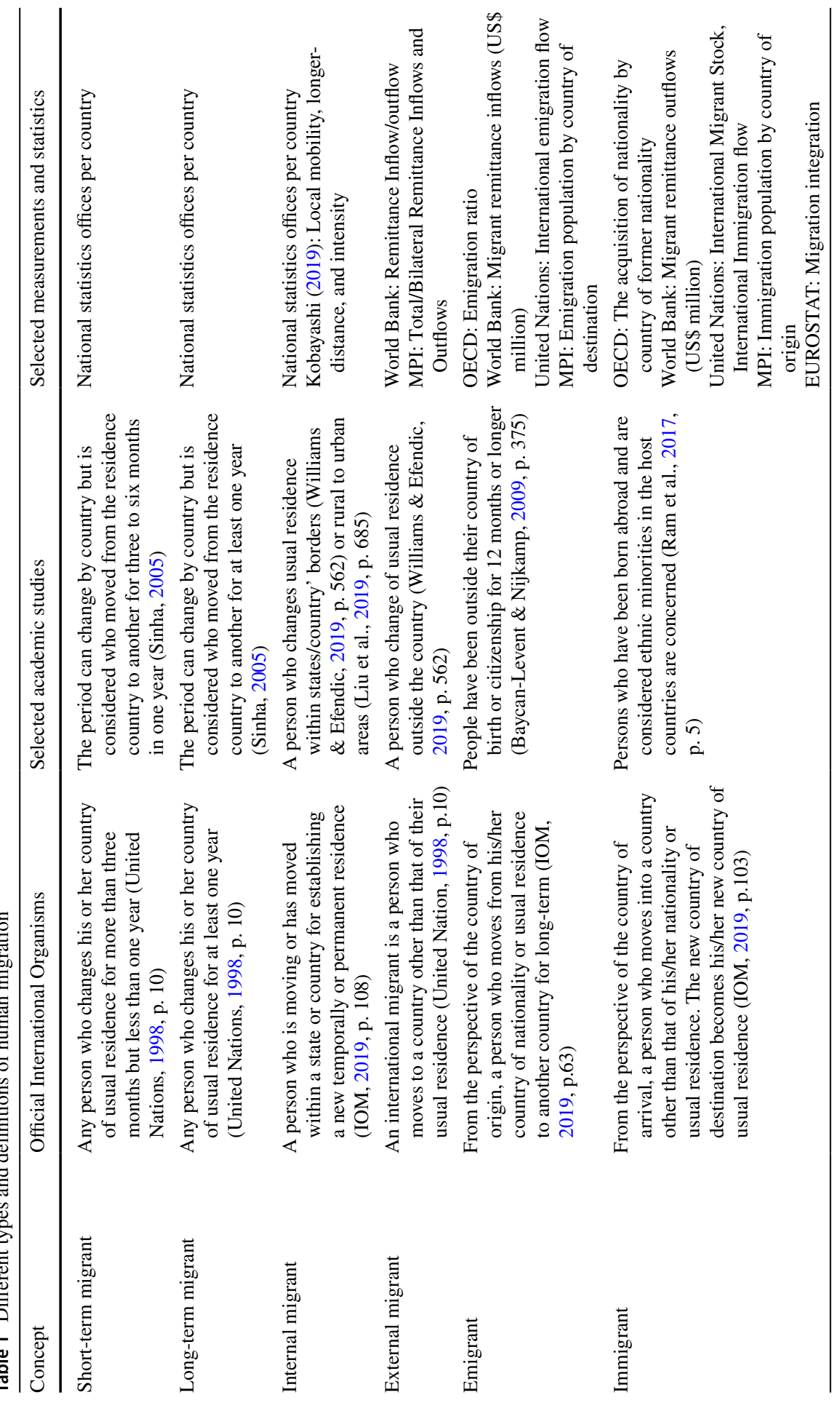




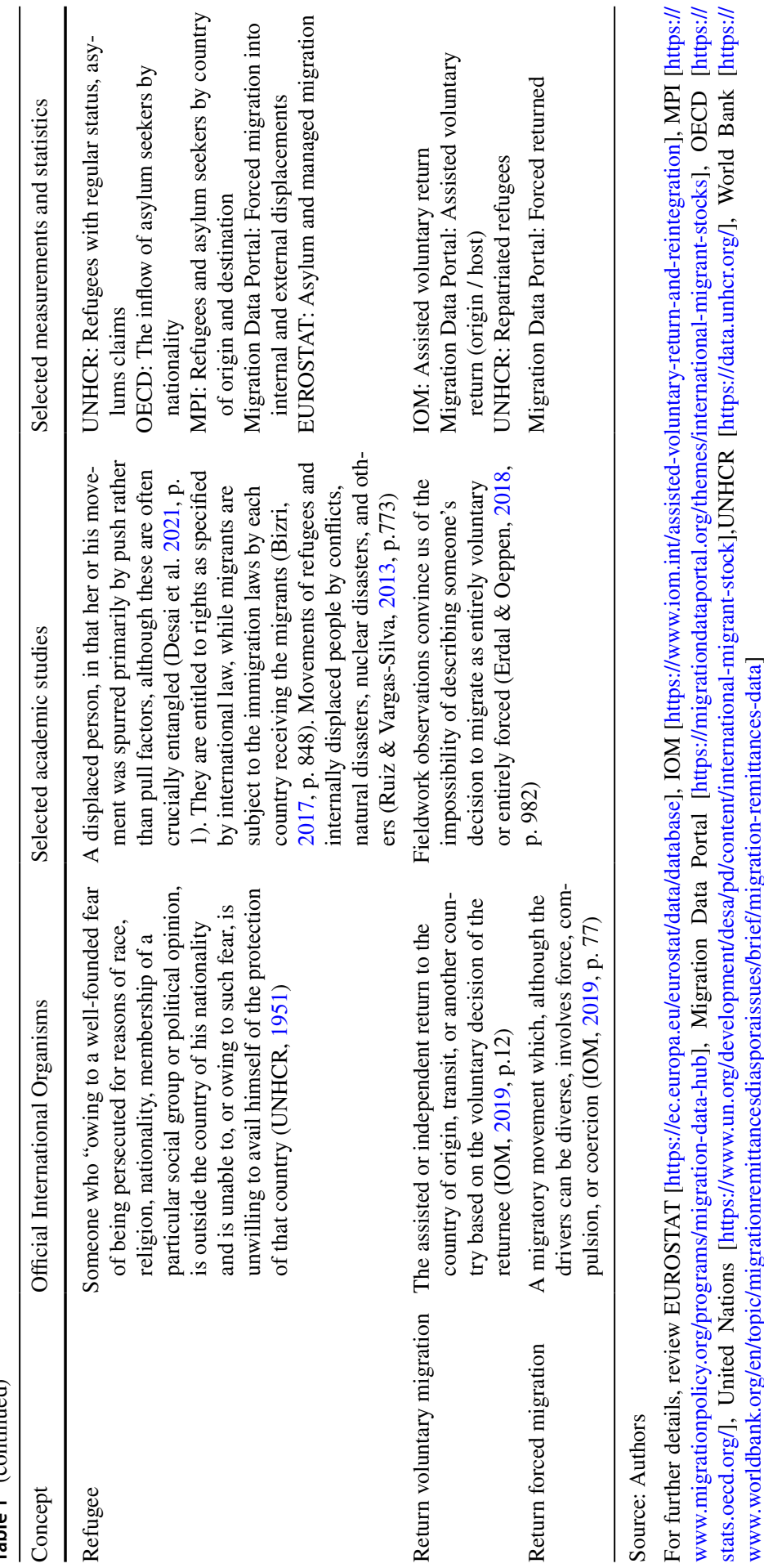


The definition of "migrant" takes special relevance in the research design of entrepreneurial migrants studies. Why? The definition will describe the main characteristics of the analyzed phenomenon, delimit the theoretical approaches and the potential match with the existing secondary sources of information (e.g., official statistics, existing databases), as well as generate new sources of information to analyze the phenomenon through primary sources (e.g., interviews, experiments, surveys). Consequently, the definition is important for a better understanding of a phenomenon, as well as for generating comparative data and useful insights that will impact policy frameworks, support programs, and made contributions for the integration of the migrant community.

Regarding the measurements, due to the lack of data and diverse critics about the quality of existing metrics about international migration, the official international organisms (IOM, OECD, United Nations, UNHCR, and others) had made several efforts to review metrics (United Nations, 2012) as well as to establish a consensus about the key definitions related to international migration (IOM, 2019). However, by reviewing the current official information, data about entrepreneurial migrants is almost inexistent. In this regard, the Global Entrepreneurship Monitor (GEM) and the Panel Studies of Entrepreneurial Dynamic (PSED) projects have contributed with insights to understanding the phenomenon of entrepreneurial migrants by introducing special questions or matching with the official statistics about migration (see Li et al., 2018; Brzozowski \& Lasek, 2019; Ashourizadeh \& Wickstrøm, 2020). Likewise, the research community that studies entrepreneurial migrants has made efforts to generate empirical evidence of this phenomenon by collecting qualitative data (e.g., cases, interviews, narratives, ethnographies) and quantitative data (e.g., surveys). Nevertheless, the production of official rigorous information and knowledge across the globe are critical issues that need to be rapidly solved for taking action and evaluating the effectiveness of the existing support programs.

\section{Migration from and in emerging economies}

Undoubtedly, migration has been the "grand societal challenge" over the last decade and will be a "grand humanitarian challenge" in the current decade. At the present moment, at least thirty-one refugee/displacement situations cover more than one hundred countries worldwide (UNHRC, 2021). It represents that approximately 79.5 million individuals, for different reasons, have been displaced from their home country to another country looking for better life conditions (see UNHRC, 2020, 2021). Table 2 shows a selection of the key migratory displacements at the present time that need to be analyzed.

Over the last decade, official statistics have shown that most of these human displacement situations occur from developing countries' people hosted in other developing countries (e.g., at least $86 \%$ of the world's refugees UNHCR statistics ${ }^{2}$ ). However, the academic debate has mainly focused on the displacement of emerging

\footnotetext{
${ }^{2}$ For further details, review the UNHCR statistics [https://www.unhcr.org/refugee-statistics/]
} 


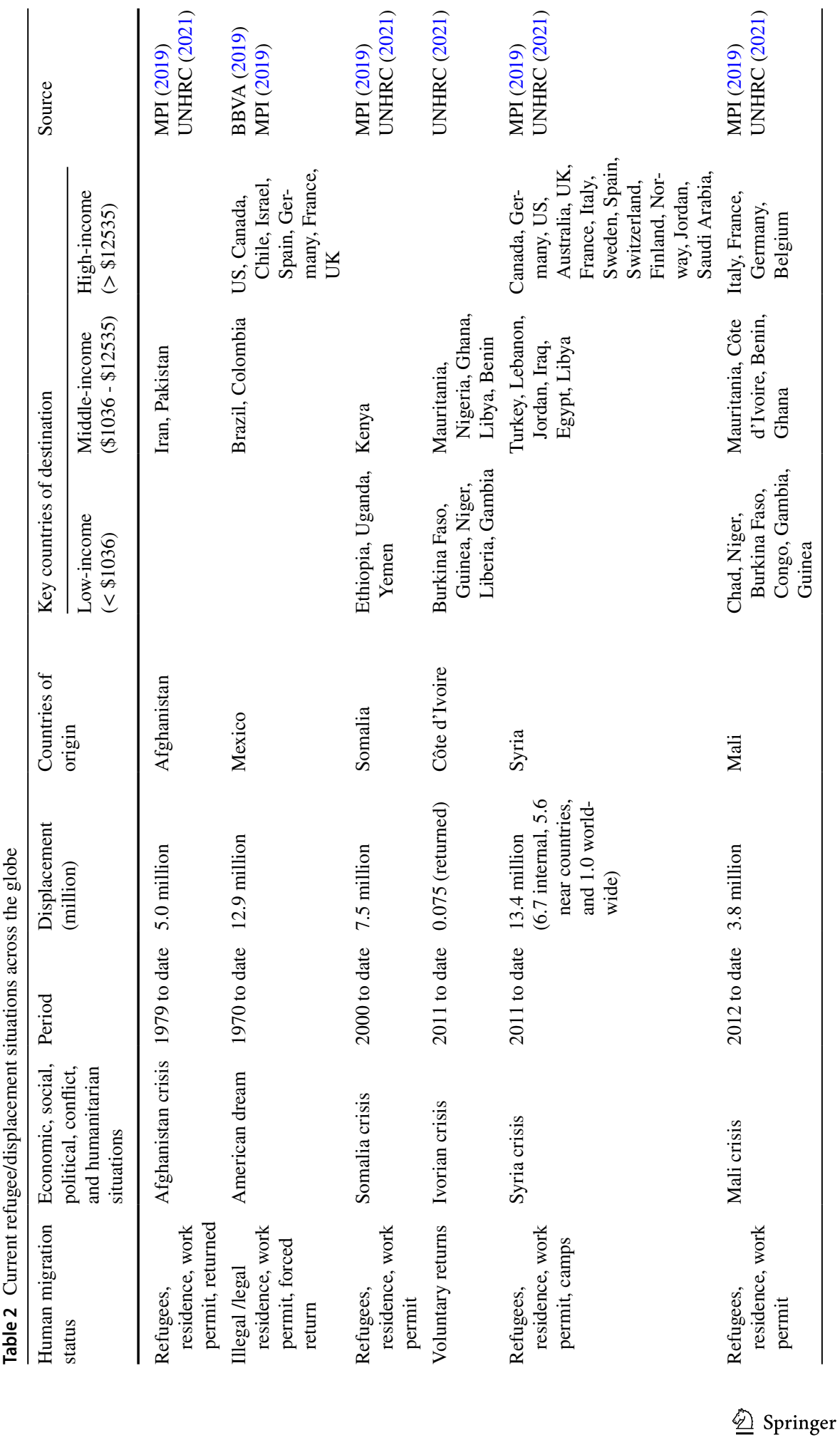




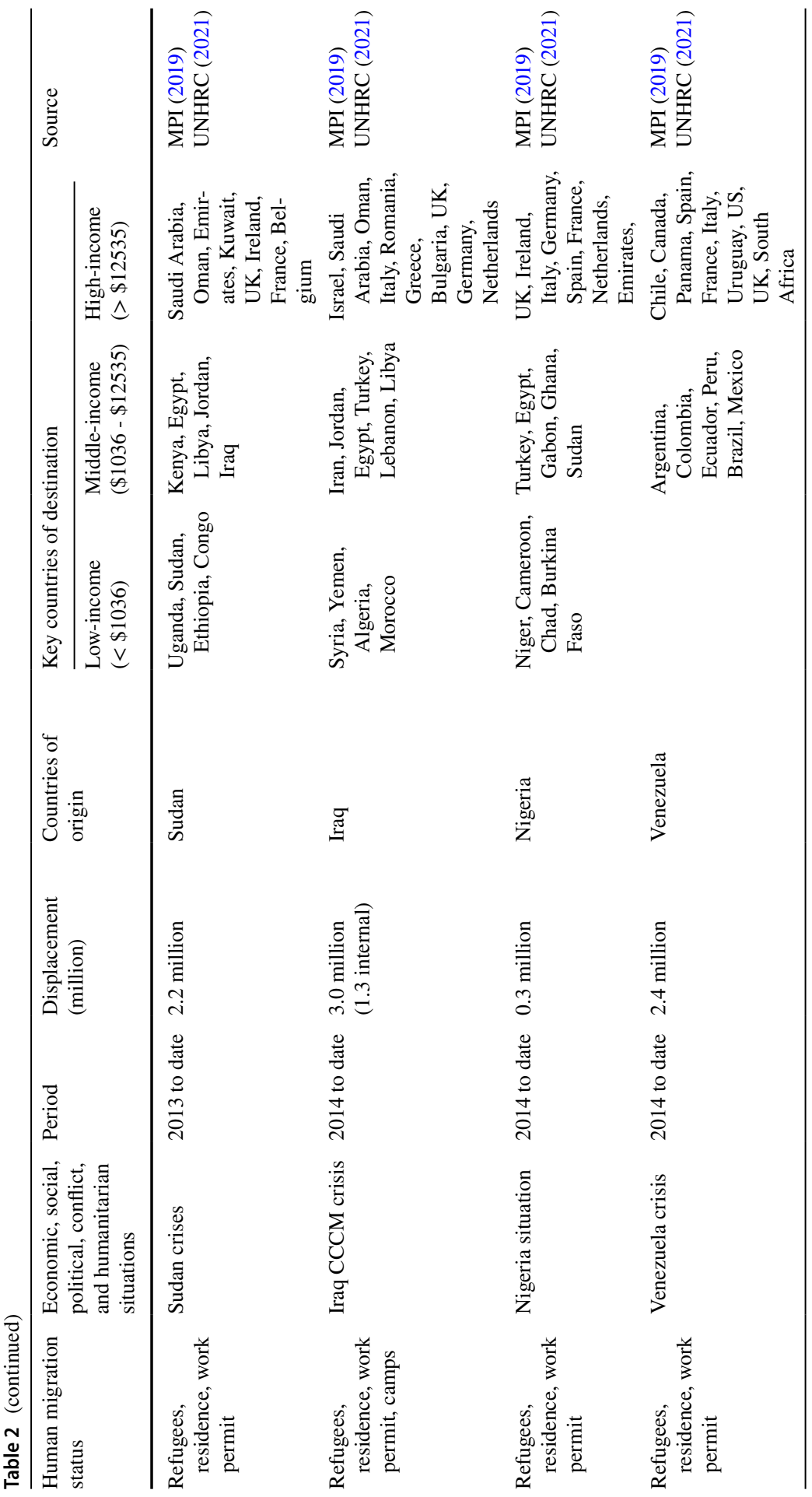




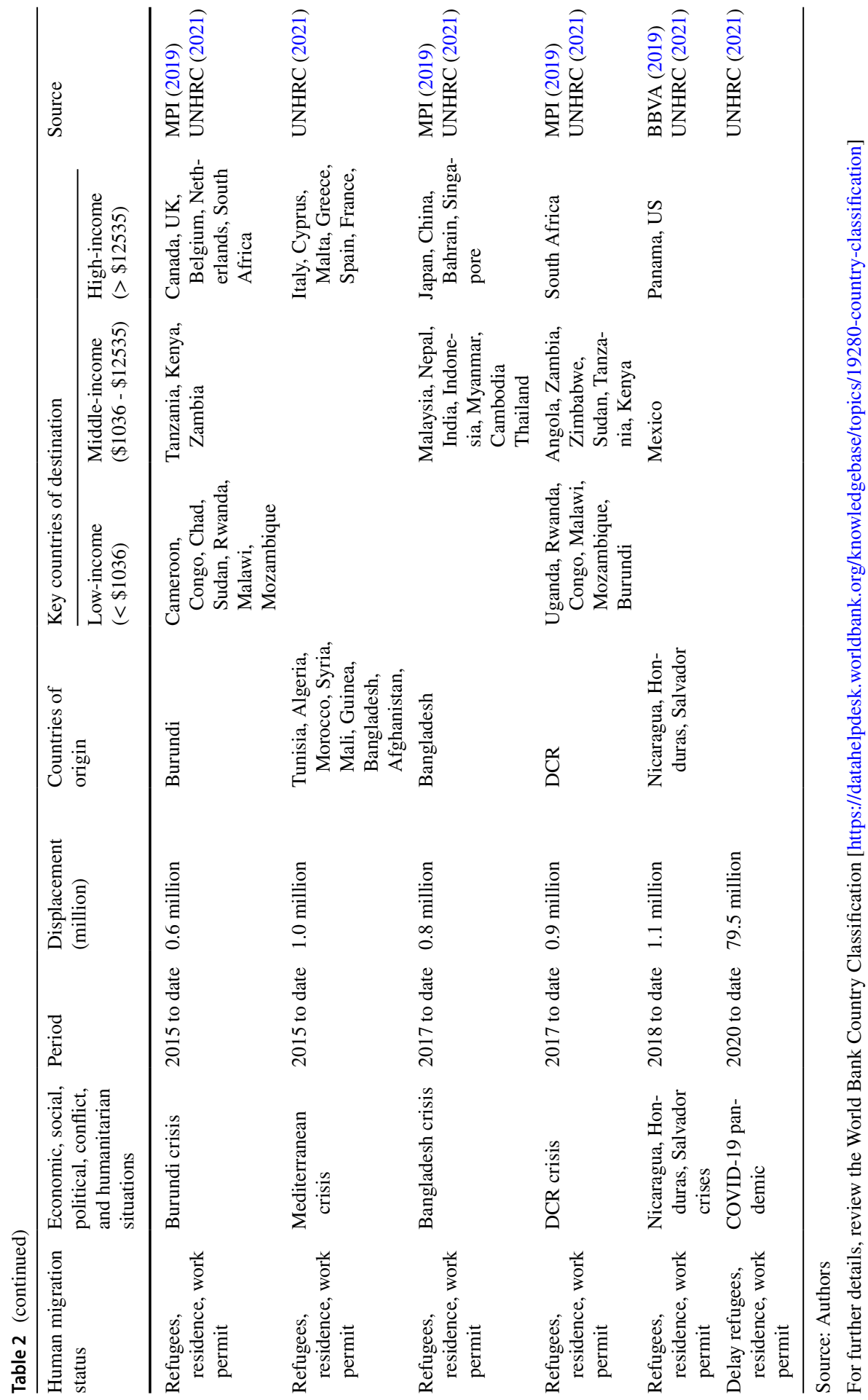


economies into developed countries (Levie, 2007; Aliaga-Isla \& Rialp, 2013; Dheer, 2018; Mawson \& Kasem, 2019). Although there is little consensus in the academic literature on which countries qualify as emerging markets or economies, previous studies have specified patterns to identify these types of economies. In this paper, an emerging market/economy can be understood as an economy characterized by low-income but with an expected rapid growth (e.g., liquidity, equity, trade volume, foreign direct investment, and regulations) that is strongly related to an engagement/ attractiveness with global markets (Skeldon, 2012) to transit from a pre-industrial stage towards an innovative stage with better living standards. Specifically, the Standard and Poor's index includes a list of emerging economies (e.g., Brazil, Chile, China, Colombia, Czech Republic, Egypt, Hungary, India, Indonesia, Malaysia, Mexico, Morocco, Peru, Philippines, Poland, Russia, South Africa, Thailand, and Turkey). Most of these countries are classified as middle-income economies according to the World Bank country classification ${ }^{3}$. Indeed, by reviewing the official statistics about international migration, the Standard and Poor's index includes diverse economies that have hosted numerous (entrepreneurial) migrants from low-income and middle-income economies (e.g., Venezuela, Guatemala, Honduras, Nicaragua, Syria, Somalia, Sudan, Iraq, Nigeria, Bangladesh, and others).

With COVID-19 now present in every country worldwide, the world's 79.5 million displaced people are among the most exposed and vulnerable communities (see UNHRC, 2020, 2021). The official organisms have highlighted at least the following five trends observed in the host countries. First, many countries have denied access to their territory of human migrants (e.g., US, Russia, Brazil, Colombia, Peru, Ecuador, India, Australia, Saudi Arabia, Morocco, Thailand, Egypt, Tanzania, Hungary, Malaysia). Second, many countries have faced the collapse of the national immigration systems that have delayed the migratory process of a massive number of refugees, migrants' residence/work permits, or renewals of residence permits (e.g., Chile, Argentina, Bolivia, China, Paraguay, South Africa). Third, some countries have implemented the COVID-19 restrictions with exceptions to refugees (e.g., Mexico, Canada, Venezuela, Europe, Iran, Afghanistan, Pakistan, Libya, Sudan, Ethiopia, Somalia, Kenya, Ghana, Niger, Nigeria, Senegal). Fourth, a few countries have not imposed COVID-19 restrictions on the entry of migrants (e.g., Guatemala, Honduras, Nicaragua, Mali, Chad, Turkey, Yemen, Tunisia, Iceland). Finally, with a few exceptions, international migrants have placed in host countries faced multiple vulnerabilities regarding access to health systems, being in the first line of the labor force of essential sectors during the pandemic (e.g., cleaning, transporting), or is not recognized by the labor market's supports. Today, there is not enough information about the role and situation of entrepreneurial migrants pre/post COVID-19 pandemic across the globe. Consequently, it is urgent to generate empirical evidence about the phenomenon of entrepreneurial migration from and in emerging economies.

\footnotetext{
${ }^{3}$ World Bank Country Classification for the 2021 fiscal year defined it based on the GNI per capita from 2020.
} 


\section{Entrepreneurial migrants taboos and stereotypes}

According to Bordalo et al. (2016, p. 1753), "stereotypes highlight differences between groups and are especially inaccurate (consisting of unlikely, extreme types) when groups may be quite similar. In this view, stereotypical thinking implies overreaction to information that generates or confirms a stereotype and underreaction to information that contradicts it. Therefore, stereotypes can change if new information changes the group's most distinctive trait". Previous studies have evidenced the persistence of several cultural "stereotypes or taboos" in the host countries regarding entrepreneurial migrants in the following three dimensions: the individual, the organizational, and the environmental. This section provides a compilation of some examples per dimension.

\section{Individual dimension: selected taboos/ stereotypes about the entrepreneurial migrant}

Regarding the individual dimension, we identified some examples of stereotypes/taboos highlighted by the following published studies related to entrepreneurial migrants:

- A "xenophobic" tendency to stigmatize immigrants, specifically those from other African countries, as criminals, people who undermine economic development and take jobs from locals (Maharaj, 2002, p. 47)

- Why are immigrants "more entrepreneurial" than natives? (Vandor \& Franke, 2016).

- Rising "xenophobia" has been found to push disproportionate numbers of migrants with limited English proficiency into self-employment in the United States (Naudé et al., 2015, p.11)

- Stereotypes about the Chinese as "hard workers", while superficially positive, easily give way to darker perceptions of them as "exploitative employers" (Chan et al., 2019, p. 1462).

- Stories and perceptions about Central and Latin American migrants are more salient in public discourse, usually as backward and "lowly-educated persons", sometimes as "criminals or perpetrators of trafficking co-nationals" (Chan et al., 2019, p. 1462).

- A narrative of "invisibility" describes migrant women as uneducated, illiterate, and passive (Vershinina \& Cruz, 2020, p.9).

- $[\ldots]$

\section{Organizational dimension: selected taboos/ stereotypes about business created by entrepreneurial migrant}

Regarding the organizational dimension, we identified some examples of stereotypes/taboos highlighted by the following published studies related to entrepreneurial migrants: 
- Inmigrant microbusiness owners tend to be "more growth-orientated" than their more local counterparts (Bosworth, 2006)

- The lack of interest in migrant entrepreneurship also stems from the belief that, unlike their European counterparts, where temporary migrants became permanent settlers in the 1970s, Asian migrants are regarded as sojourners and are unlikely to establish "successful business ventures" (Rahman \& Lian, 2010, p. 254).

- In Western countries, migrant-owned businesses in cities tend to be "smallscaled vendors" resembling newly arrived immigrants (Liu et al., 2019, p. 682).

- Negative racial stereotypes about their links to "criminal organizations and illegal activity" are also relatively common across Latin America (Chan et al., 2019, p. 1462).

- Migrants and diasporas are commonly seen as having a deficit-necessity position in society and as entrepreneurs [...] may mobilize diverse resources that "foster business development" and "support internationalization processes", which may happen transnationally linking home and host contexts [...] the resources of migrants and diasporas are addressed as even superior for international business, and seen as particular assets (Elo et al., 2018, p. 121).

- $[\ldots]$

\section{Environmental dimension: selected taboos/ stereotypes about entrepreneurial migrant in home and host countries}

Regarding the environmental dimension, we identified some examples of stereotypes/taboos highlighted by the following published studies related to entrepreneurial migrants:

- Rural immigration as a "potential catalyst" for economic

- regeneration based on in-migrants business activity (Stockdale \& Findlay, 2004)

- Within debates on migration and development, migrants are often expected to be "super entrepreneurs" who will benefit development in home and host countries through their greater prowess as entrepreneurs, their remittances, their transnational entrepreneurial activity, and their business acumen (Naudé et al., 2015, p.2).

- There is a cultural consensus that "Chinese bosses are stingy/exploitative" creates a stereotype that distinguishes Chinese bosses from other ethnic groups (e.g., white Australians). Again, there is a racial hierarchy in the Australian job market because people tend to think that ethnic Chinese bosses, as compared to white Australian bosses, are more exploitative and seldom follow the employment laws (Li, 2020, p. 741).

- "Negative perceptions" among migrant communities who view the financial risk to investments, lack of support, political fragmentation, and weak institutional framework as barriers to investment (Williams \& Efendic, 2019, p. 560).

- Refugees face "discrimination" in formal labor markets, they may become necessity-entrepreneurs or self-employed (Desai et al., 2021, p.7).

- $[\ldots]$ 
Given the variety of forms that entrepreneurial migrants can take, their distinctive characteristics, and challenges involved in the conjunction between entrepreneurship and migration status, this line of research represents fertile ground for contributing to the literature by breaking existing taboos and stereotypes.

\section{Special issue's contributions}

Achieving the SI objectives, our initial call for paper received more than 35 manuscripts that were pre-selected adopting the fit with the SI and contributions. After the pre-selection process, eleven manuscripts were invited to participate in the review process. Finally, eight manuscripts covered the reviewers' criteria of quality and were accepted for being part of this special issue. Table 3 summarizes the manuscripts' contributions to this special issue. Following Wickert et al. (2020) suggestions, we explain how each paper extended previous studies with new insights that could break taboos or stereotypes related to entrepreneurial migrants from/in emerging economies, as well as, we highlight their scholarly impacts on the academic community, the entrepreneurial migrant community, and the policymakers community enrolled in emerging economies.

\section{Contributions to the individual dimension's taboos/ stereotypes}

The Vershinina and Cruz (2020) study paid attention to the taboo/stereotype related to identifying the dominant and marginal voices in migrant entrepreneurship form/ in emerging contexts. This theoretical piece highlights the importance of ethnography to give the voice to migrants for a better understanding of their events, processes, and entrepreneurial initiatives. The scholarly contributions of this study for the academic community are extending the academic debates about new methods and a fresh understanding of the complex narratives of migration dynamics. Regarding the practical implications, the study would legitimize the relevance of migrants' stories of entrepreneurship as well as provide a better understanding of the entrepreneurial migrants' characteristics and impacts for the definition of adequate policy frameworks.

The Guerrero et al. (2021) study paid attention to the taboo/stereotype related to how high-skilled migrants face labor market discrimination in the displacements within Latin American emerging countries (e.g., strongly related to the phenomenon of Venezuelan mobility). More concretely, the authors tested why migrants from emerging economies are more entrepreneurial than natives in another emerging economy. Using a sample of 13368 individuals collected during the 2016 and 2017 Global Entrepreneurship waves in Chile, the study shows that high-skilled migrant in a dynamic emerging economy (Chile) is not a guarantee of success in the labor market. However, it is a determinant for the international entrepreneur. Based on these results, the study contributes to three academic debates: (a) migrants are more entrepreneurial than natives; (b) environment selection and discrimination conditions; and (c) the quality of migrant entrepreneurship. The main implications for the 
entrepreneurial migrant community are the legitimization of their role in the hosted countries, as well as the importance of resource allocation and the management of migrants' capabilities. For policymakers, the study highlights the importance of a policy design that promotes the integration and the recognition of the professional skills of migrants in the host countries.

The Santamaria-Velasco et al. (2021) study paid attention to the entrepreneurial process of migrants by linking individual and institutional conditions. This study focuses on the grand societal challenge faced by the forced mobilization of people from Central-American and the Caribbean countries towards an emerging economy (Mexico). The study collected qualitative retrospective case studies to adopt the human capital, institutional voids, and institutional distance approaches. The authors mapped the drivers/barriers of refugees' entrepreneurial processes by considering the personal background, human capital, social capital, and institutional distances. As a result, the study extends the academic debates about the individual paradigms (qualified human capital versus unskilled human capital) and the institutional paradigms (short and long-distance) within the migrants and refugee collectives. The study shows some useful implications for the insertion of refugees into host society as potential entrepreneurs and the drivers/barrier that refugees face across the entrepreneurial process in host emerging economies (Mexico). For policymakers, the study encourages the re-formulation of effective policies that support the refugees' collective.

\section{Contributions to the organizational dimension's taboos/ stereotypes}

The Poblete and Mandakovic (2020) study paid attention to the taboo/ stereotype related to the quality of entrepreneurial initiatives. It is connected with the mobilization of people within the South American emerging economies. By adopting a socio-cognitive approach, the study analyzes the early-stage innovative entrepreneurs from emerging economies hosted in Chile. Using 5713 early-stage entrepreneurs collected during the 2016-2018 Global Entrepreneurship Monitor in Chile, the results show that migrant who feels capable of successfully starting a business will be likely to conduct innovative entrepreneurship. The study extends the academic debate about whether and how behavior is regulated in cognitive processes and contextual elements. For entrepreneurial migrants, the study highlights that the creation of innovative ventures by migrants strongly depends on their perceived self-efficacy and the differentiation strategies in host markets. For policymakers, the study provides practical insights about migration flow to design policies that encourage a smooth and positive integration.

The Bolzani et al. (2020) study paid attention to the international potential of high-tech initiatives associated with the migrants' mobility from emerging economies (LATAM, East Europe, Africa) to developed economies (Italy). The authors analyze the desirability and feasibility of migrants' exporting. Using an experimental design that matches 108 natives and migrants in high-tech initiatives, the results show that the perceived feasibility of exporting has a stronger effect on the perceived likelihood of exporting in the distant future (i.e., when entrepreneurs 


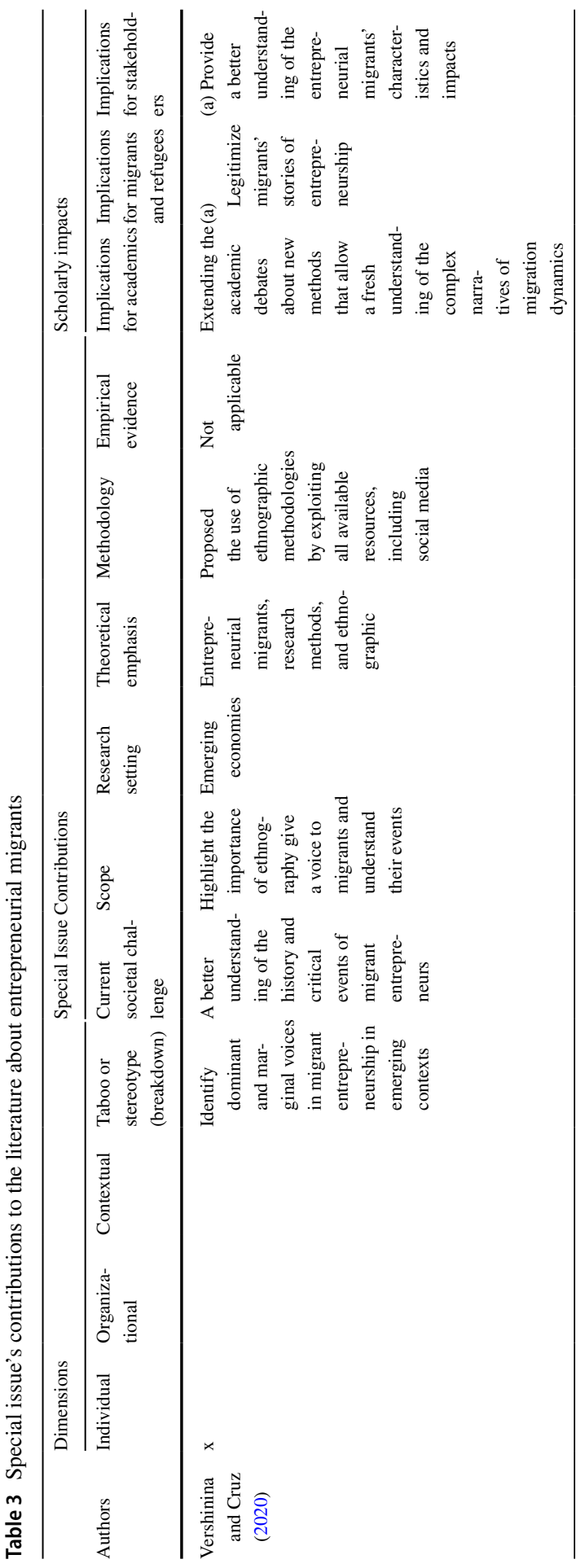




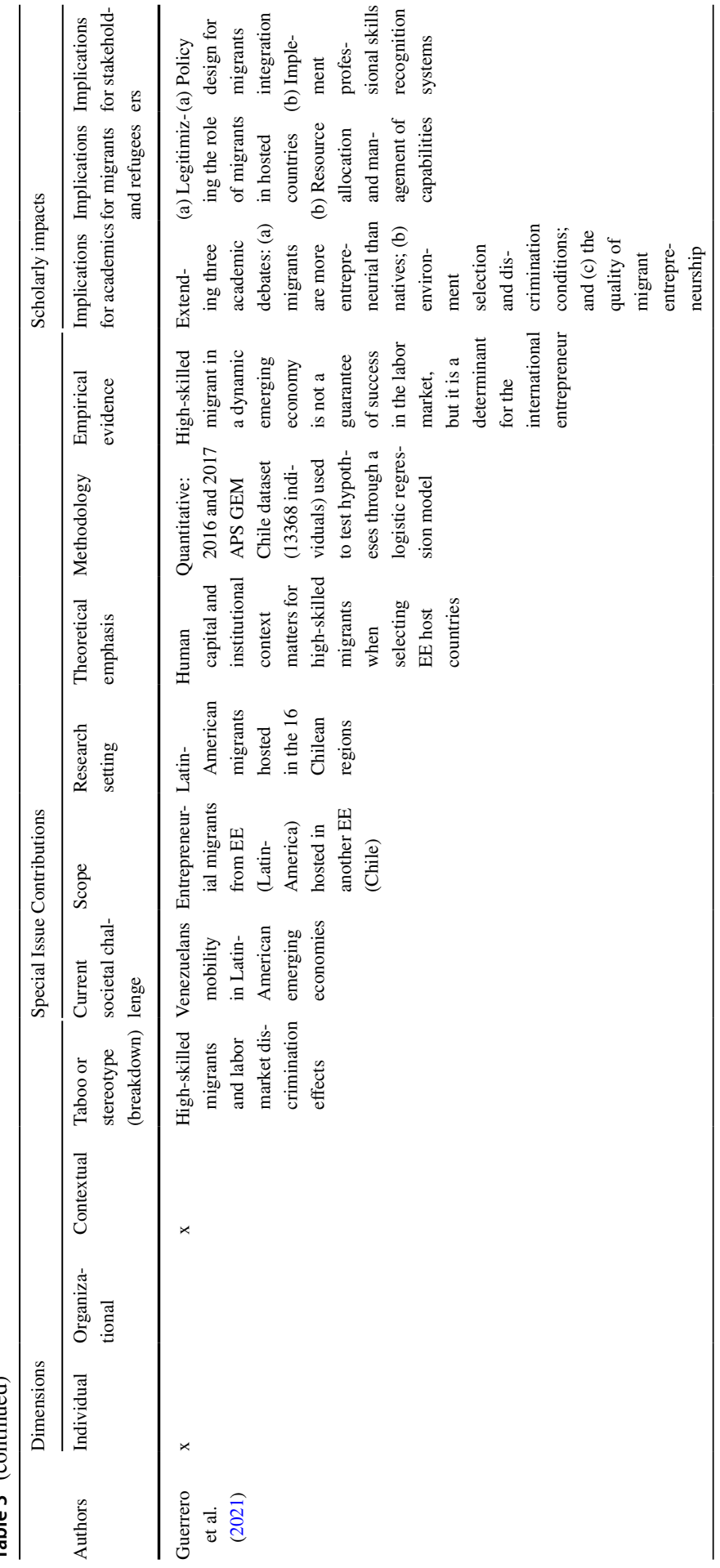




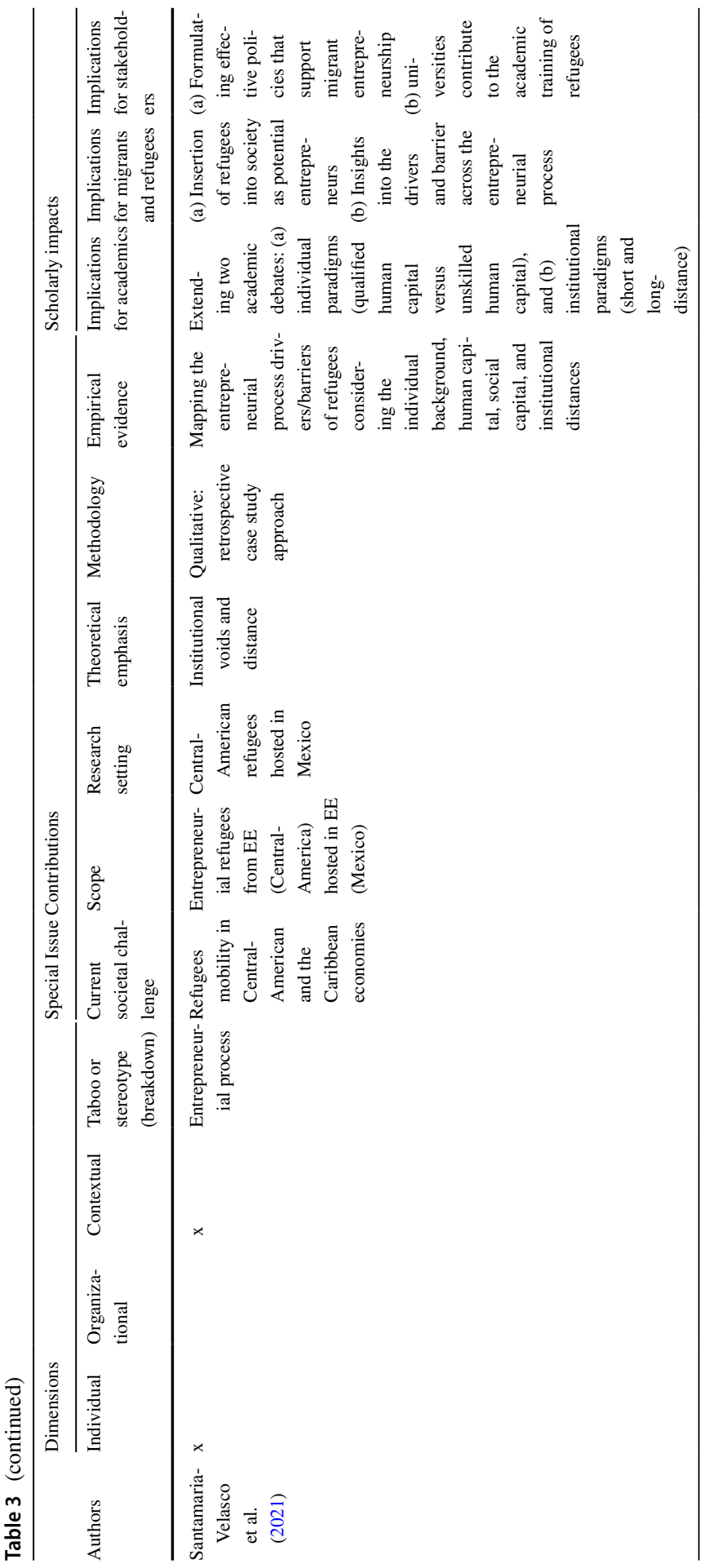




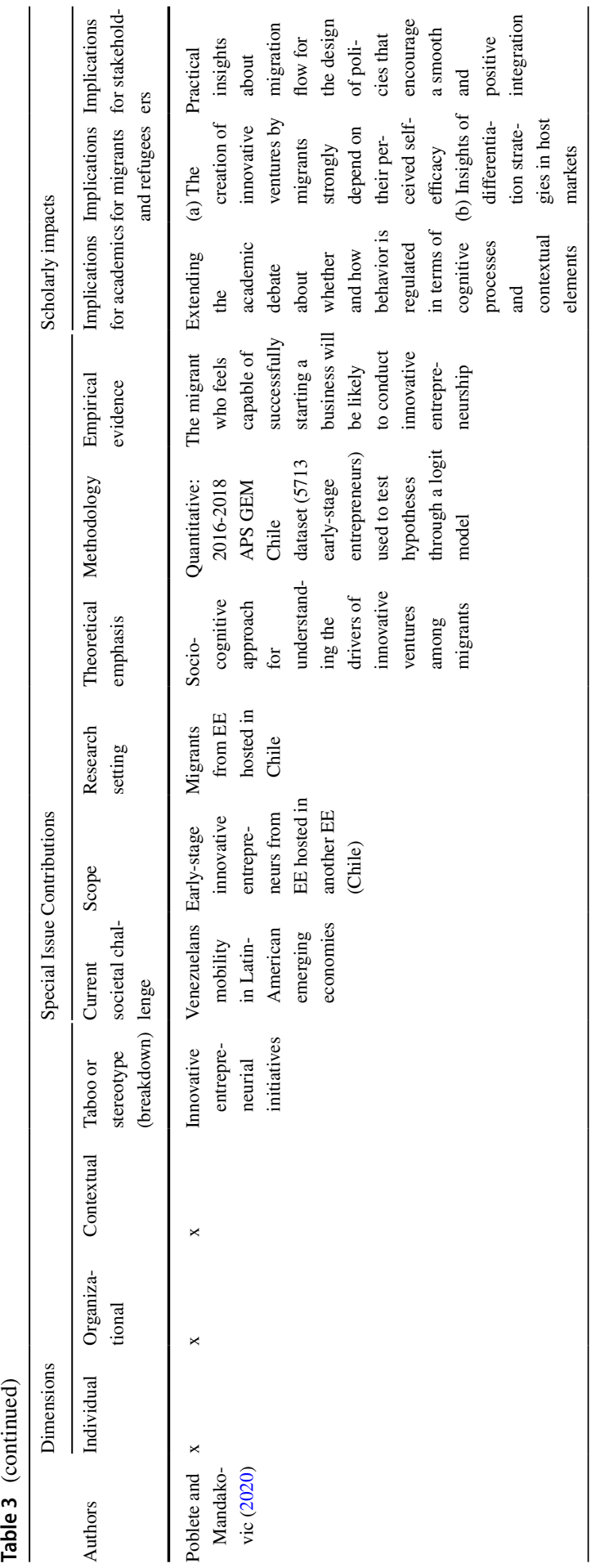




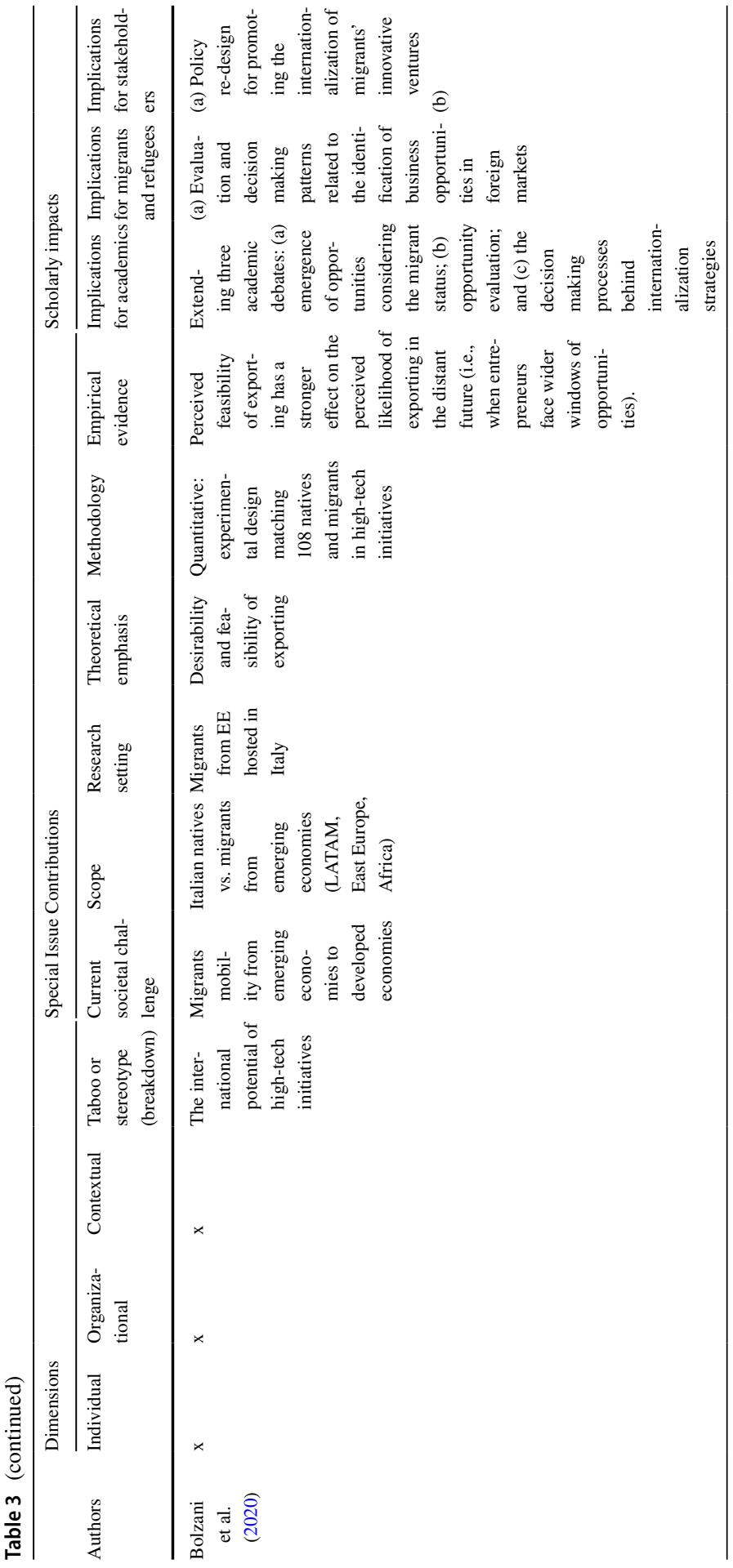




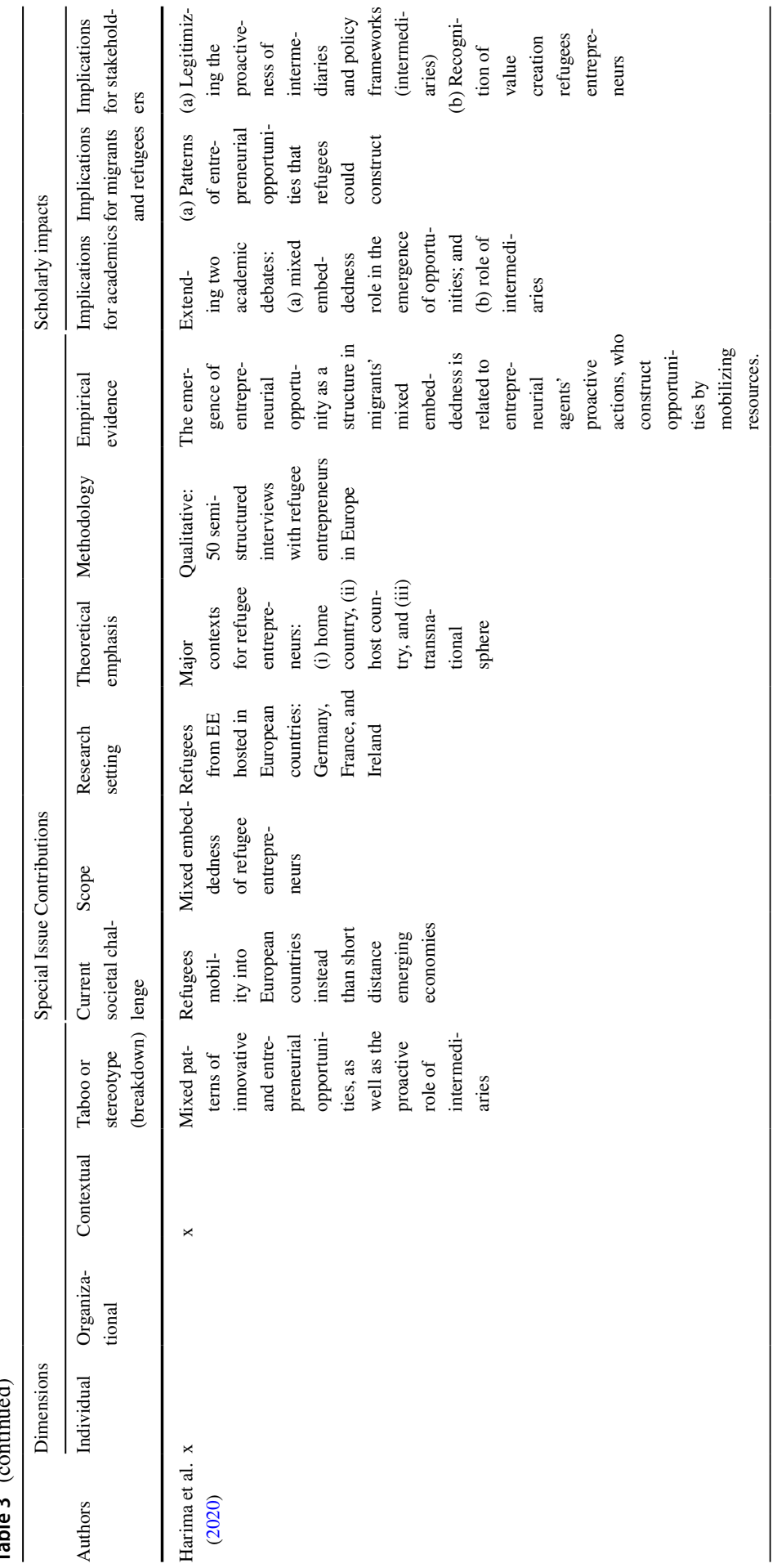




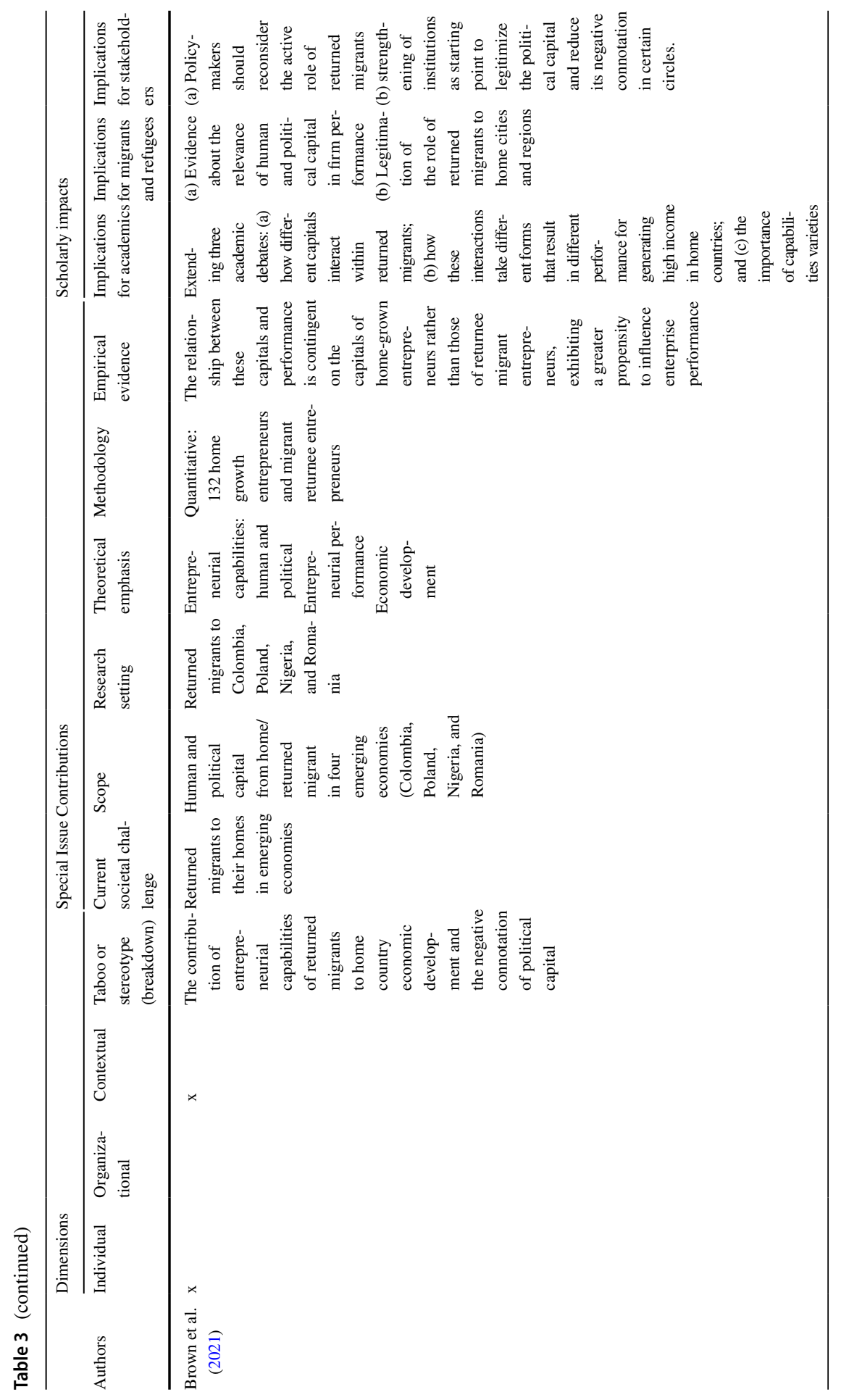




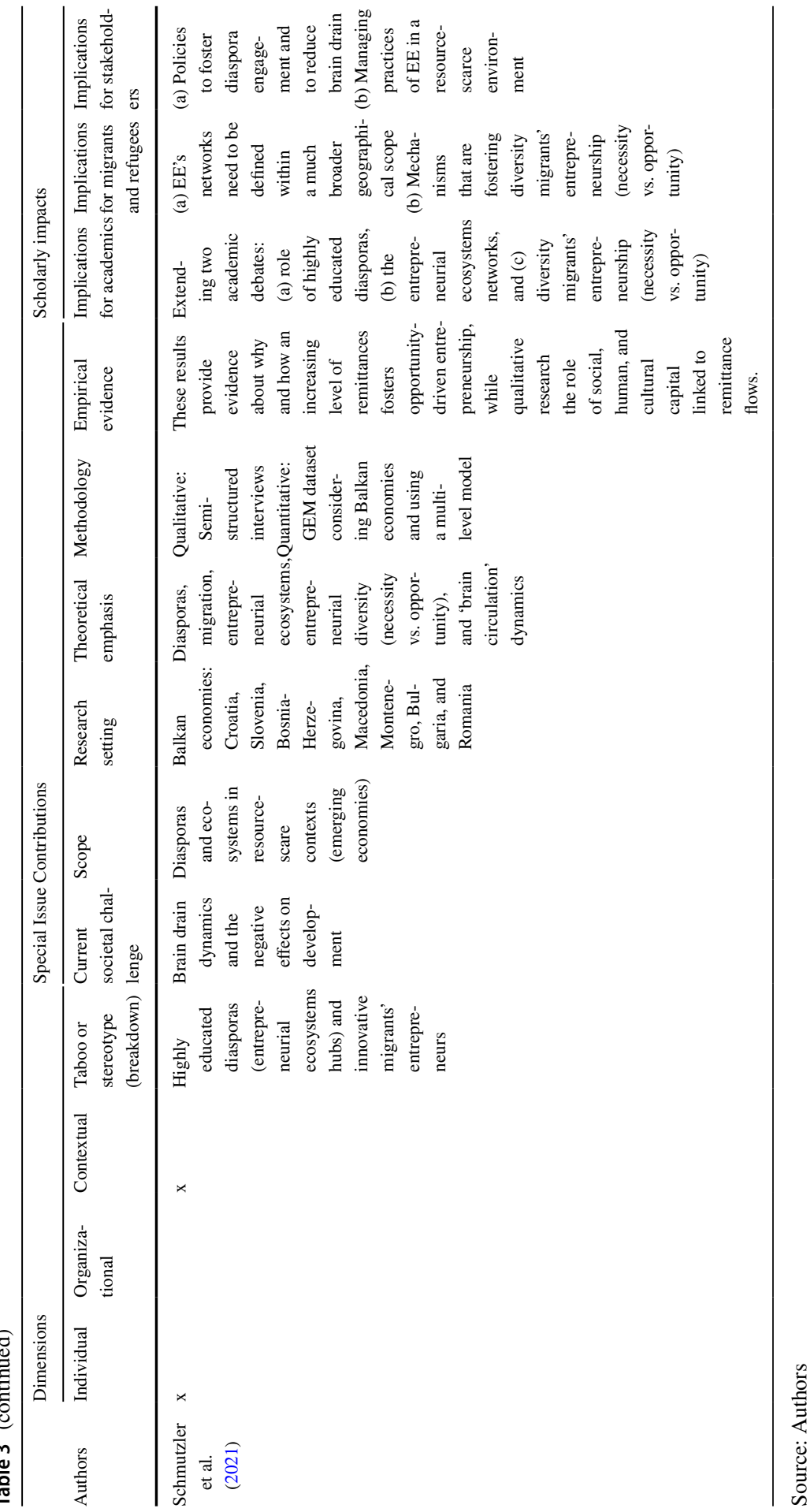


face wider windows of opportunities). The study extends the following three academic debates: (a) emergence of opportunities considering the migrant status; (b) opportunity evaluation; and (c) the decision-making processes behind internationalization strategies. The main implications are linked with the evaluation and decision-making patterns related to the identification of business opportunities in foreign markets, as well as policy re-design for promoting the internationalization of migrants' innovative ventures.

\section{Contributions to the environmental dimension's taboos/ stereotypes}

The Harima et al. (2020) study paid attention to the taboo/ stereotype related to the proactive role of intermediaries for engaging innovative or entrepreneurial patterns in the identification of opportunities by entrepreneurial refugees. It is strongly connected with the big societal challenge of refugees' mobility into European countries instead of the short distance with some emerging economies. More concretely, the study focuses on the mixed embeddedness of refugee entrepreneurs from emerging economies hosted in Germany, France, and Ireland, as well as the role of intermediaries in this configuration. Using 50 semi-structured interviews with refugee entrepreneurs, the results show that the emergence of entrepreneurial opportunity as a structure in migrants' mixed embeddedness is related to entrepreneurial agents' proactive actions, who construct opportunities by mobilizing resources. In this vein, the study extending the academic debates about (a) mixed embeddedness role in the emergence of opportunities; and (b) the role of intermediaries. Indeed, provide several patterns of entrepreneurial opportunities that refugees could construct that could be useful for this collective. For policymakers, the study's implications are focused on legitimizing the proactiveness of intermediaries and policy frameworks (intermediaries) and the recognition of value creation refugees entrepreneurs in the host countries.

The Brown et al. (2021) study paid attention to the taboo/ stereotype related to the contribution of entrepreneurial capabilities of returned migrants to home country economic development and the negative connotation of political capital. The study analyzes the role of human and political capital from home/returned migrants on performance and economic development in four emerging economies (Colombia, Poland, Nigeria, and Romania). Using a sample of 132 home growth entrepreneurs and migrant returnee entrepreneurs, the results show that the relationship between these capitals and performance is contingent on the capitals of home-grown entrepreneurs rather than those of returnee migrant entrepreneurs, exhibiting a greater propensity to influence enterprise performance. The study extends the following three academic debates: (a) how different capitals interact within returned migrants; (b) how these interactions take different forms that result in different performance for generating high income in home countries; and (c) the importance of capabilities varieties. The main implications are linked to the relevance of human and political capital in firm performance, the legitimation of the role of returned migrants to home cities and regions, the reconsideration of the active role of returned migrants during the policy development framework, and strengthening of institutions as 
starting point to legitimize the political capital and reduce its negative connotation in certain circles.

The Schmutzler et al. (2021) study paid attention to the taboo/ stereotype related to highly educated diasporas (entrepreneurial ecosystems hubs) and innovative migrants' entrepreneurs. It is linked to brain drain dynamics and the negative effects on development among Balkan economies (e.g., Croatia, Slovenia, BosniaHerzegovina, Macedonia, Montenegro, Bulgaria, and Romania). More concretely, the authors explore diasporas and ecosystems in resource-scare contexts (emerging economies) using mixed methods. The results provide empirical evidence about why and how an increasing level of remittances fosters opportunity-driven entrepreneurship, while qualitative research the role of social, human, and cultural capital linked to remittance flows. As a result, the study is extending two academic debates: (a) role of highly educated diasporas, (b) the entrepreneurial ecosystems networks, and (c) diversity migrants' entrepreneurship (necessity vs. opportunity). Regarding policy implications, the authors highlight that policies should foster diaspora engagement to reduce brain drain and manage practices of EE in a resource-scarce environment.

\section{Proposed research agenda}

Future research should adopt mixed theoretical (e.g., behavioral, organizational, institutional, economical, sociological, psychological) and improving methodological approaches (e.g., cross-section, multi-level, longitudinal, experimental, single/ multiple cases, narrative, ethnographies) to covers the gap related to migrants from/ in emerging economies engaging in entrepreneurship in the following dimensions.

\section{The migrant}

The human capital dimension has been applied to entrepreneurship literature (Martin et al., 2013). Human capital plays an important role in entrepreneurial migrants for host countries. A wealthy host country attracts talented people from developing/developing economies (Mahroum, 2000). Highly skilled migrants participate in the host labor market when they pass the entry labor market conditions to protect host country employees (Kloosterman, 2010; Williams \& Krasniqi, 2018; Wei et al., 2019; Guerrero et al., 2021). To contribute to this academic debate, we encourage future research to incite the discussion on (i) the flow of talent from/in emerging economies; (ii) the integration of migrants in the local labor markets; (iii) the role of entrepreneurship as an integration platform in emerging economies, and (iv) the human capital component among entrepreneurial migrants' teams.

The cognitive dimension deals with the understanding of how entrepreneurs think. As a stream of research, it is defined as the knowledge structures that people use to make assessments, judgments, or decisions involving opportunity evaluation and venture creation and growth. Studies based on a social-situated approach have 
suggested that the thinking that underlies entrepreneurship is not static, but dynamics, since people act within specific a variety of active environments with varying degrees of distribution of such thinking across minds and tools. Therefore, migration as a phenomenon may provide an interesting context for the ongoing development of this study area (Poblete, 2018; Poblete \& Mandakovic, 2020). To contribute to this academic debate, we encourage potential authors to incite the discussion on the four themes of socially situated cognitions (action-oriented, embodied, situated, and distributed) within entrepreneurial migrants.

Gendered symbolic capital dimension Despite recent large flows of migrants, the gendered nature of how men and women experience migrant entrepreneurial journeys remains under-researched (Chreim et al., 2018). To contribute to this academic debate, we encourage future researchers to incite the discussion on building theory or/an evidencing about (i) the lived experiences of transnational migrant entrepreneurs setting up enterprises outside of their host country context (Vershinina et al., 2019); (ii) the rarely discussed form of symbolic capital understood as the prestige, status and positive reputation individuals possess in the eyes of others; and (iii) the multifaceted and often gendered nature of forms of cultivated symbolic (Afreh et al., 2019; Spark et al., 2019).

\section{The business created by migrants}

Family business and diasporas A family angle on entrepreneurship is important to discuss migrant and diaspora businesses (Harima, 2014; Discua Cruz \& Basco, 2019; Elo et al., 2018). Migrants and their families engage in various roles and positions as entrepreneurs, intrapreneurs, family business owners, and managers in their countries of origin and residence. To contribute to this academic debate, we encourage potential authors to provoke the discussion on (i) the social networks, social capital, and social embeddedness, together with family dynamics, long-term intentions, and even succession paths that foster entrepreneurship within regions and across borders (Rautiainen et al., 2019); (ii) the migration issues around families, clans, ethnic communities and global diasporas that influence entrepreneurs and their operations (Pérez \& Lluch, 2016); and (iii) the most appropriate methods to examine the dynamics of generations of migrant families in business and transnational diaspora.

Innovative and international business The link between entrepreneurship, innovation, and internationalization angles is an advancing view of migration from/in emerging economies (Elo et al., 2018; Poblete \& Mandakovic, 2020; Bolzani et al., 2020). By living in different cultures, migrants encounter opportunities to introduce/ adapt their products/services to the host customers' preferences and transfer innovations/technologies based on the needs of the home customers. To contribute to this academic debate, we encourage potential authors to incite the discussion on (i) the innovation introduced by migrants from and in emerging economies; (ii) the internationalization process of migrants from and in emerging economies; and (iii) the 
role of migrants in academic entrepreneurship and technology transfer (Guerrero \& Urbano, 2017; Siegel \& Guerrero, 2021).

Social and sustainable business A social enterprise angle is another theme to discuss migration from and in emerging economies. An increasing number of migrants engage in transnational social entrepreneurship, which involves using commercial activities within home-host countries to solve problems in origin countries (Qin \& Estrin, 2015; Honig, 2018; Bolzani et al., 2019). To contribute to this academic debate, we encourage potential authors to incite the discussion on (i) the determinants and the patterns adopted by migrants during the creation of social business in the host or/and in the home country; (ii) the outcomes and impacts generated by social entrepreneurs; and (iii) the elements associated with the construction of a social entrepreneurship identity.

\section{Migrants' home and host countries}

Institutional distance Current policy interventions to facilitate/regulate entrepreneurial activity sometimes result in different outcomes for migrant entrepreneurs, particularly within resource-constrained contexts as emerging economies (Krieger et al., 2018). Regional conflicts and the recurrent influx of migrants/refugees into emerging economies from multiple emerging economies conflict sites underlie the intense entrepreneurial activity located around designated refugee zones and border towns (Prime \& Wanjiru, 2017). To contribute to the academic debate related to institutional distance and migrants from/in emerging economies, it is important to analyze: (i) the role of contextual embeddedness in migrant entrepreneurial opportunities; (ii) capturing the economic impacts of migrant entrepreneurship on economic growth in emerging economies; (iii) effective policymaking to facilitate international entrepreneurial ecosystems within resource-constrained contexts.

Policy guides \& impacts Policy guides focus on the role of entrepreneurship in enhancing the positive effects on well-being, economic, and technological development (Ratha et al., 2011; Guerrero \& Urbano, 2019; Guadagno, 2020; UNHCR, 2020). Policy plays an important role in supporting entrepreneurial activity by (and for) refugees/migrants and addressing the obstacles faced in economic activity. This special issue expects to contribute to the academic debate and policymakers debate by provoking the discussion on (i) the role of governments and development partners on the design/implementation of agendas for promoting entrepreneurship for migrants/refugees, (ii) the study of cases/good practices replicated by emerging economies, (iii) the implemented metrics to capture the value of these policies, (iv) the adequate methods to measure reverse impacts (migrants' contributions), (v) the COVID-19 challenges faced by the migrant community, and (v) the combating inequalities within and among emerging economies. 


\section{Conclusions}

Entrepreneurial migration from/in emerging economies, as grand societal and humanitarian challenges that we currently face, underscores the need for scholarly research. In our role as social science researchers, this special issue aims to stimulate scholars from different social science fields to rethink more broadly about the opportunities for making an impact with our research focus on entrepreneurial migration from/in emerging economies and begin doing so more often (see Wickert et al., 2020, p. 316). We believe that it is the perfect time to "make a difference" through our research, teaching, and interaction with multiple socioeconomic agents to constitute impacts that "endorse a real transformation" for supporting the migrants' community.

Acknowledgments The authors are grateful to the AOM Entrepreneurship Division for sponsoring our PDW entitled "Entrepreneurial Migrants from and in Emerging Economies" during the 79th Annual Meeting of the Academy of Management, as well as the PDW participants for their contributions about this topic. Our special recognition to Professor Salvador Roig (IEMJ former editor) for his invaluable support along this exciting entrepreneurial editorial journey. We also express our gratitude to all the anonymous peer reviewers who participated during the review process by donating their time, constructive feedback, and insightful comments that contributed substantially to the special issue manuscripts' development. Thanks also to all contributors for highlighting a better understanding of this phenomenon. Last but not least, we recognize the support from the Faculty of Economics and Business (Universidad del Desarrollo, Chile), iNCITE- Northumbria Centre for Innovation, Regional Transformation and Entrepreneurship (Newcastle Business School, Northumbria University, UK), and CIRCLE- Centre for Innovation Research (Lund University).

\section{References}

Afreh, B., Rodgers, P., Vershinina, N., \& Williams, C. C. (2019). Varieties of context and informal entrepreneurship: Entrepreneurial activities of migrant youths in rural Ghana. International Journal of Entrepreneurial Behavior \& Research. https://doi.org/10.1108/IJEBR-02-2018-0109

Aliaga-Isla, R., \& Rialp, A. (2013). Systematic review of immigrant entrepreneurship literature: previous findings and ways forward. Entrepreneurship \& Regional Development, 25(9-10), 819-844.

Ashourizadeh, S., Li, J., \& Wickstrøm, K. A. (2020). Immigrants Entrepreneurial networks and export: A comparative study. International Entrepreneurship and Management Journal, 1-28.

Bates, T. (2011). Minority Entrepreneurship, Foundations and Trends® in Entrepreneurship, 7(3-4), pp. $151-311$.

Baycan-Levent, T., \& Nijkamp, P. (2009). Characteristics of migrant entrepreneurship in Europe'. Entrepreneurship \& Regional Development, 21(4), 375-397.

BBVA. (2019). Yearbook of migration and remittances. Mexico: Fundación BBVA. Available at: https:// www.bbvaresearch.com/en/publicaciones/mexico-yearbook-of-migration-and-remittances-2019/\#: $\sim:$ text $=$ It's $\% 20 \mathrm{a} \% 20$ publication $\% 20$ of $\% 20$ CONAPO,remittances $\% 20$ worldwide $\% 20$ and $\% 20 \mathrm{in} \%$ 20Mexico

Bizri, R. M. (2017). Refugee-entrepreneurship: a social capital perspective'. Entrepreneurship \& Regional Development, 29(9-10), 847-868.

Bolzani, D., Fini, R., \& Marzocchi, G. L. (2020). The influence of entrepreneurs' immigrant status and time on the perceived likelihood of exporting. International Entrepreneurship and Management Journal. https://doi.org/10.1007/s11365-020-00704-8

Bolzani, D., Marabello, S., \& Honig, B. (2019). Exploring the multi-level processes of legitimacy in transnational social enterprises. Journal of Business Venturing. https://doi.org/10.1016/j.jbusvent. 2019.06.002 
Bordalo, P., Coffman, K., Gennaioli, N., \& Shleifer, A. (2016). Stereotypes. The Quarterly Journal of Economics, 131(4), 1753-1794.

Bosworth, G. (2006). Counterurbanisation and job creation: entrepreneurial in-migration and rural economic development. CRE Discussion Paper.

Brown, A., Meriton, R., Gerardou, F., Bhandal, R., Devinney, T., \& Kafouros, M. (2021). Migrant human and political capitals value in entrepreneur enterprise performance. A Comparative Study of Four Emerging Markets. https://doi.org/10.1007/s11365-020-00710-w

Brzozowski, J., \& Lasek, A. (2019). The impact of self-employment on the economic integration of immigrants: Evidence from Germany. Journal of Entrepreneurship, Management and Innovation, 15(2), 11-28.

Chan, C., Ramírez, C., \& Stefoni, C. (2019). Negotiating precarious labor relations: dynamics of vulnerability and reciprocity between Chinese employers and their migrant workers in Santiago. Chile, Ethnic and Racial Studies, 42(9), 1456-1475.

Chreim, S., Spence, M., Crick, D., \& Liao, X. (2018). Review of female immigrant entrepreneurship research: Past findings, gaps and ways forward. European Management Journal.

Dabić, M., Vlačić, B., Paul, J., Dana, L. P., Sahasranamam, S., \& Glinka, B. (2020). Immigrant entrepreneurship: A review and research agenda. Journal of Business Research, 113, 25-38.

De Haas, H. (2005). International migration, remittances and development: myths and facts. Third World Quarterly, 26(8), 1269-1284.

Desai, S., Naudé, W. A., \& Stel, N. M. (2021). Refugee entrepreneurship: context and directions for future research. Small Business Economics.

Dheer, R. J. (2018). Entrepreneurship by immigrants: a review of existing literature and directions for future research. International Entrepreneurship and Management Journal, 14(3), 555-614.

Discua Cruz, A., \& Basco, R. (2019). A family perspective on Entrepreneurship. In N. Turcan R \& Fraser (Ed.), A Handbook of Multidisciplinary Perspectives on Entrepreneurship (pp.147-176). Palgrave.

Elo, M., Sandberg, S., Servais, P., Basco, R., Cruz, A. D., Riddle, L., \& Täube, F. (2018). Advancing the views on migrant and diaspora entrepreneurs in international entrepreneurship. Journal of International Entrepreneurship, 16(2), 119-133.

Erdal, M. B., \& Oeppen, C. (2018). Forced to leave? The discursive and analytical significance of describing migration as forced and voluntary. Journal of Ethnic and Migration Studies, 44(6), 981-998.

Pérez, P. F., \& Lluch, A. (Eds.). (2016). Evolution of family business: Continuity and change in Latin America and Spain. Edward Elgar Publishing.

Guadagno, L. (2020). Migrants and the COVID-19 pandemic: An initial analysis. (p. 60). International Organization for Migration.

Guerrero, M., \& Urbano, D. (2017). The impact of Triple Helix agents on entrepreneurial innovations' performance: An inside look at enterprises located in an emerging economy. Technological Forecasting and Social Change, 119, 294-309.

Guerrero, M., \& Urbano, D. (2019). Effectiveness of technology transfer policies and legislation in fostering entrepreneurial innovations across continents: an overview. The Journal of Technology Transfer, $1-20$.

Guerrero, M., Mandakovic, V., Apablaza, M., \& Arriagada, V. (2021). Are migrants in/from emerging economies more entrepreneurial than natives? International Entrepreneurship and Management Journal. https://doi.org/10.1007/s11365-020-00714-6

Harima, A. (2014). Network dynamics of descending diaspora entrepreneurship: Multiple case studies with Japanese entrepreneurs in emerging economies. Journal of Entrepreneurship, Management and Innovation, 10(4), 65-92.

Harima, A., Periac, F., Murphy, T., \& Picard, S. (2020). Entrepreneurial Opportunities of Refugees in Germany, France, and Ireland: Multiple Embeddedness Framework. International Entrepreneurship and Management Journal. https://doi.org/10.1007/s11365-020-00707-5

Honig, B. (2018). Exploring the intersection of transnational, ethnic, and migration entrepreneurship. Journal of Ethnic and Migration Studies, 1-17.

Huang, S. (2012). Taiwanese Entrepreneurs Saying Goodbye to the U.S., Hello to China. Forbes.

IOM. (2019). Glossary on migration, IML Series No. 34. Switzerland: International Organization for Migration. Available at: https://publications.iom.int/system/files/pdf/iml_34_glossary.pdf

IOM. (2020). World Migration Report. Switzerland: International Organization for Migration. Available at: https://publications.iom.int/system/files/pdf/wmr_2020.pdf 
Kloosterman, R. C. (2010). Matching opportunities with resources: A framework for analyzing (migrant) entrepreneurship from a mixed embeddedness perspective. Entrepreneurship and Regional Development, 22(1), 25-45.

Kobayashi, A. (2019). International Encyclopedia of Human Geography. Elsevier.

Krieger, T., Renner, L., \& Ruhose, J. (2018). Long-term relatedness between countries and international migrant selection. Journal of International Economics, 113, 35-54.

Levie, J. (2007). Immigration, in-migration, ethnicity and entrepreneurship in the United Kingdom. Small Business Economics, 28(2), 143-169.

Li, C., Isidor, R., Dau, L. A., \& Kabst, R. (2018). The more the merrier? Immigrant share and entrepreneurial activities. Entrepreneurship Theory and Practice, 42(5), 698-733.

Li, Y.-T. (2020). Disharmonious Chinese ethnic business: intergroup stereotypes among Chinese migrant employees in Australia. Ethnic and Racial Studies, 43(4), 732-750.

Liu, C. Y., Ye, L., \& Feng, B. (2019). Migrant entrepreneurship in China: entrepreneurial transition and firm performance. Small Business Economics, 52(3), 681-696.

Maharaj, B. (2002). Economic refugees in post-apartheid South Africa - Assets or liabilities? Implications for progressive migration policies 1. GeoJournal, 56(1), 47-57.

Mahroum, S. (2000). Highly skilled globetrotters: mapping the international migration of human capital. $R \& D$ Management, 30(1), 23-32.

Martin, B. C., McNally, J. J., \& Kay, M. J. (2013). Examining the formation of human capital in entrepreneurship: A meta-analysis of entrepreneurship education outcomes. Journal of business venturing, 28(2), 211-224.

Mawson, S., \& Kasem, L. (2019). Exploring the entrepreneurial intentions of Syrian refugees in the UK. International Journal of Entrepreneurial Behavior \& Research.

MPI. (2019). Immigrant and Emigrant Populations by Country of Origin and Destination Statistics. Available at: https://www.migrationpolicy.org/programs/data-hub/charts/immigrant-and-emigrantpopulations-country-origin-and-destination?width $=1000 \&$ height $=850 \&$ iframe $=$ true

Naudé, W., Siegel, M., \& Marchand, K. (2015). Migration, entrepreneurship and development: A critical review. IZA Journal of Migration, 6(1), 5.

Poblete, C. (2018). Shaping the castle according to the rocks in the path? Perceived discrimination, social differences, and subjective well-being as determinants of firm type among immigrant entrepreneurs. Journal of International Entrepreneurship, 16(2), 276-300.

Poblete, C., \& Mandakovic, V. (2020). Innovative outcomes from migrant entrepreneurship: a matter of whether you think you can, or think you can't. International Entrepreneurship and Management Journal. https://doi.org/10.1007/s11365-020-00705-7

Prime, K., \& Wanjiru, R. (2017). Comparing institutional determinants of economic growth in developing regions. New Directions.

Qin, F., \& Estrin, S. (2015). Does Social Influence Span Time and Space? Evidence from Indian Returnee Entrepreneurs, Strategic Entrepreneurship Journal, 9(3), 226-242.

Rahman, M. M., \& Lian, K. F. (2010). The Development of Migrant Entrepreneurship in Japan: Case of Bangladeshis'. Journal of International Migration and Integration / Revue de l'integration et de la migration internationale. https://doi.org/10.1007/s12134-010-0158-0

Ram, M., Jones, T., \& Villares-Varela, M. (2017). Migrant entrepreneurship: Reflections on research and practice. International Small Business Journal, 35(1), 3-18.

Ratha, D., Mohapatra, S., \& Scheja, E. (2011). Impact of migration on economic and social development: A review of evidence and emerging issues. World Bank. https://doi.org/10.1596/1813-9450-5558

Rautiainen, M., Rosa, P., Pihkala, T., \& Parada, M. J. (2019). \& Discua Cruz, A. The Family Business Group Phenomenon..

Rodríguez-Gutiérrez, M. J., Romero, I., \& Yu, Z. (2019). Guanxi and risk-taking propensity in Chinese immigrants' businesses. International Entrepreneurship and Management Journal, 1-21.

Ruiz, I., \& Vargas-Silva, C. (2013). The economics of forced migration. The Journal of Development Studies, 49(6), 772-784.

Santamaria-Velasco, C. A., del Mar Benavides-Espinosa, M., \& Simón-Moya, V. (2021). The refugee entrepreneurship process from/in emerging economies. International Entrepreneurship and Management Journal. https://doi.org/10.1007/s11365-020-00712-8

Schmutzler, J., Andonova, V., \& Perez-Lopez, J. (2021). The role of diaspora in opportunity-driven entrepreneurial ecosystems: A mixed-methods study of Balkan economies. International Entrepreneurship and Management Journal. https://doi.org/10.1007/s11365-020-00708-4 
Siegel, D., \& Guerrero, M. (2021). The impact of quarantines, lockdowns, and "reopenings" on the commercialization of science: Micro and macro issues. Journal of Management Studies. https://doi.org/ 10.1111/joms.12692

Sinha, B. R. K. (2005). Human migration: concepts and approaches. Foldrajzi Ertesito, 3(4), 403-414.

Skeldon, R. (2012). China: An emerging destination for economic migration. Retrieved from Migration Policy Institute.

Spark, C., Cox, J., \& Corbett, J. (2019). Gender, political representation and symbolic capital: how some women politicians succeed. Third World Quarterly, 1-20.

Stockdale, A., \& Findlay, A. (2004). Rural in-migration: a catalyst for economic regeneration. Global Change and Human Mobility.

UNHCR. (1951). Convention and Protocol Relating to the status of refugees. Geneva: United Nations. Available at: https://www.unhcr.org/3b66c2aa10

UNHCR. (2018). Global Trends: Forced displacement in 2018. Available at: https://www.unher.org/ globaltrends2018/

UNHCR. (2020). COVID-19 Temporary Measures and Impact on Protection. United Nations. Available at: https://im.unhcr.org/covid19_platform/

UNHRC. (2021). Statistic data about refugees' situations. Geneva: United Nations. Available at: https:// data.unhcr.org/en/situations

United Nations. (1998). Recommendations on Statistics of International Migration. Washington: United Nations Statistics Division. Available at: https://unstats.un.org/unsd/publication/seriesm/seriesm_ 58rev1e.pdf

United Nations. (2012). Review of Sources and Quality of Statistics on International Migration in selected countries of the Commonwealth of Independent States. Geneva: United Nations. Available at: https://unece.org/DAM/stats/publications/Review_of_Sources_on_International_Migration_ FINAL.pdf

United Nations. (2017). Trends in International Migrant Stock: The 2017 revision (United Nations database, POP/DB/MIG/Stock/Rev.2017). Department of Economic and Social Affairs. Population Division.

Vandor, P., \& Franke, N. (2016). Why are immigrants more entrepreneurial. Harvard Business Review, 27.

Vershinina, N., \& Cruz, A. D. (2020). Researching migrant entrepreneurship communities: a reflection through collaborative (auto) ethnographies. International Entrepreneurship and Management Journal. https://doi.org/10.1007/s11365-020-00706-6

Vershinina, N., Rodgers, P., Mcadam, M., \& Clinton, E. (2019). Transnational migrant entrepreneurship, gender and family business. Global Networks, 19(2), 238-260.

Wei, X., Jiao, Y., \& Growe, G. (2019). Language skills and migrant entrepreneurship: evidence from China. Small Business Economics, 53(4), 981-999.

Wickert, C., Post, C., Doh, J. P., Prescott, J. E., \& Prencipe, A. (2020). Management Research that Makes a Difference: Broadening the Meaning of Impact. Journal of Management Studies.

Williams, N., \& Krasniqi, B. A. (2018). Coming out of conflict: How migrant entrepreneurs utilize human and social capital. Journal of International Entrepreneurship, 16(2), 301-323.

Williams, N., \& Efendic, A. (2019). Internal displacement and external migration in a post-conflict economy: Perceptions of institutions among migrant entrepreneurs. Journal of International Entrepreneurship, 17(4), 558-585.

Publisher's Note Springer Nature remains neutral with regard to jurisdictional claims in published maps and institutional affiliations. 